\title{
Electrochemical Reduction Behavior of Carbon Dioxide on Sintered Zinc Oxide Electrode in Aqueous Solution
}

\author{
Shoichiro IKEDA, ${ }^{\text {* }}$ Atsushi HATTORI, ${ }^{\mathrm{a}}$ Masunobu MAEDA, ${ }^{\mathrm{a}}$ Kaname ITO, \\ and Hidetomo NODA ${ }^{\mathrm{c}}$
}

\begin{abstract}
aDepartment of Applied Chemistry, Nagoya Institute of Technology(Gokiso-cho, Showa-ku, Nagoya, 466-8555, Japan)
bLate Emeritus Professor of Nagoya Institute of Technology(Gokiso-cho, Showa-ku, Nagoya, 466-8555, Japan)

${ }^{\mathrm{c}}$ Chubu Electric Power Company, Inc.(Kitasekiyama, Odaka-cho, Midori-ku, Nagoya, 459-8522, Japan)
\end{abstract}

\section{Received June 4, 1999 ; Accepted December 24, 1999}

\begin{abstract}
The electrocatalytic properties of a sintered $\mathrm{ZnO}$ electrode in electroreduction of $\mathrm{CO}_{2}$ were investigated in aqueous solutions of several potassium salts. The reduction product from $\mathrm{CO}_{2}$ was only $\mathrm{CO}$ (faradaic efficiency $=70 \%$ at -1.4 $\mathrm{V}$ vs. Ag- $\mathrm{AgCl}$ in $0.1 \mathrm{~mol} / \mathrm{dm}^{3} \mathrm{KHCO}_{3}$ solution) with a considerable amount of $\mathrm{H}_{2}$ as a byproduct. The $\mathrm{ZnO}$ was found to have a higher electrocatalytic activity for $\mathrm{CO}$ formation than metallic $\mathrm{Zn}$, since the potential showing a maximal faradaic efficiency for $\mathrm{CO}$ formation was nobler by $200-250 \mathrm{mV}$ than that of the $\mathrm{Zn}$ electrode. The partial current density for $\mathrm{CO}$ formation on the $\mathrm{ZnO}$ electrode in $0.1 \mathrm{~mol} / \mathrm{dm}^{3} \mathrm{KH}_{2} \mathrm{PO}_{4}$ solution was 10 to 50 times higher than that on a $\mathrm{Zn}$ foil electrode. The sum of the faradaic efficiencies for $\mathrm{CO}$ and $\mathrm{H}_{2}$ formation did not reach $100 \%$, the difference from which was attributed to the faradaic efficiency for the reduction of the electrode itself. The metallic $\mathrm{Zn}$ thus formed on the electrode surface played no significant role in the electroreduction of $\mathrm{CO}_{2}$.
\end{abstract}

Key Words : Carbon Dioxide, Zinc Oxide, Electroreduction, Potassium Salts

\section{Introduction}

Recently, the electrochemical reduction (electroreduction) of carbon dioxide $\left(\mathrm{CO}_{2}\right)$ on various metal electrodes has been investigated by many authors using of different kinds of electrodes. ${ }^{1-6)}$

It is well known that conductive metal oxides have high catalytic activities for the production of $\mathrm{Cl}_{2}$ and $\mathrm{O}_{2}$ from $\mathrm{NaCl}$ solution and for the reduction of $\mathrm{O}_{2} .^{7-13)}$ Thus, these oxides have attracted researchers' attention as the electrode materials for the electroreduction of $\mathrm{CO}_{2 .}{ }^{14,15)}$ For example, Furuya et al ${ }^{16)}$ reported that the gas diffusion electrodes loaded with $\mathrm{ZnS}$ or $\mathrm{ZnO}$ as a catalyst were active for $\mathrm{CO}$ formation from $\mathrm{CO}_{2}$.

In previous paper ${ }^{17,18)}$ the authors reported that the $\mathrm{Zn}$ metal foil electrode reduced $\mathrm{CO}_{2}$ in aqueous dectrolytes to $\mathrm{HCOO}^{-}$and $\mathrm{CO}$, in the formation of which the oxide layer formed on the electrode surface played a certain role. In the present work, so that the role of the zinc oxide layer was understood, a sintered $\mathrm{ZnO}$ electrode was employed for the electroreduction of $\mathrm{CO}_{2}$ in aqueous solutions of several potassium salts.

\section{Experimental}

Specimen electrodes were sintered polycrystalline $\mathrm{ZnO}$ tablets of an apparent working surface of $0.94 \mathrm{~cm}^{2}$. They were prepared by iso-static pressing of $\mathrm{ZnO}$ powder (1.0 g) of reagent-grade (Nakarai Tesque, Inc.; $>99.0 \%$ ) under $147 \mathrm{MPa}$, and then sintered for 4 hours at $1473 \mathrm{~K}$ in air. Ohmic contacts were made with an In-Ga alloy $(7: 3$ by atomic ratio). The rest of the surface was shielded by epoxy resin after connecting with a $\mathrm{Cu}$ lead wire. Aqueous solutions of $\mathrm{KHCO}_{3}\left(0.1 \mathrm{M} ; \mathrm{M}=\mathrm{mol} / \mathrm{dm}^{3}\right), \mathrm{K}_{2} \mathrm{SO}_{4}$
$(0.05 \mathrm{M}), \mathrm{K}_{3} \mathrm{PO}_{4}(0.1 \mathrm{M}), \mathrm{K}_{2} \mathrm{HPO}_{4}(0.05 \mathrm{M})$, and $\mathrm{KH}_{2} \mathrm{PO}_{4}$ $(0.1 \mathrm{M})$ were prepared from regent grade chemicals and doubly distilled water. Each solution was pre-electrolyzed for $12 \mathrm{~h}$ at a current density of $40 \mu \mathrm{A} / \mathrm{cm}^{2}$ with platinized Pt electrodes, while purifled $\mathrm{N}_{2}$ was bubbled. The $\mathrm{pH}$ values of the $\mathrm{KHCO}_{3}, \mathrm{~K}_{2} \mathrm{SO}_{4}, \mathrm{~K}_{3} \mathrm{PO}_{4}, \mathrm{~K}_{2} \mathrm{HPO}_{4}$ and $\mathrm{KH}_{2} \mathrm{PO}_{4}$ solutions saturated with $\mathrm{CO}_{2}$ were about $6.8,4.2,6.8,6.1$, and 4.2 , respectively at $298 \mathrm{~K}$. A catholyte of $40 \mathrm{ml}$ was degassed by bubbling purified $\mathrm{CO}_{2}$ gas in a Pyrex cell ${ }^{2}$ ? prior to electrochemical experiments. The electroreduction experiments were usually carried out for $40 \mathrm{C}$ at 298 $\mathrm{K}$ by combination of a potentio/galvanostat (Hokuto Denko; HA-301) and an electronic coulometer (Hokuto Denko ; HF-201). The electrodes were polished with alumina powder $(0.05 \mu \mathrm{m})$ and then etched in $2 \mathrm{M} \mathrm{HCl}$ for $30 \mathrm{~s}$. They were rinsed with doubly distilled water. Cyclic voltammograms were measured between the rest potential and $-1.8 \mathrm{~V}$ vs. an $\mathrm{Ag}-\mathrm{AgCl}$ saturated $\mathrm{KCI}$ reference electrode at $50 \mathrm{mV} / \mathrm{s}$ under $\mathrm{N}_{2}$ or $\mathrm{CO}_{2}$ atmosphere in the $\mathrm{KHCO}_{3}$ or $\mathrm{K}_{2} \mathrm{SO}_{4}$ solution immediately after the immersion of the electrode in the solution. The $\mathrm{pH}$ of each solution under $\mathrm{N}_{2}$ atmosphere was adjusted to the same value as that under $\mathrm{CO}_{2}$ atmosphere by adding an appropriate amount of $2 \mathrm{M} \mathrm{H}_{2} \mathrm{SO}_{4}$ solution. The electroreduction products were analyzed by gas chromatography and high performance liquid chromatography as described previously. ${ }^{2}$ The X-ray diffractometry (XRD) using CuKoradiation (JEOL Ltd.; JDX-7E) was carried out so that the phases of the electrode surface before and after the electrolysis were observed. 


\section{Results}

3. 1 Cyclic voltammograms and reduction products

Figure 1 shows the cyclic voltammograms on the $\mathrm{ZnO}$ electrode in the $\mathrm{KHCO}_{3}$ and $\mathrm{K}_{2} \mathrm{SO}_{4}$ solutions under $\mathrm{N}_{2}$ (dotted lines) and $\mathrm{CO}_{2}$ atmospheres (solid lines). The reduction currents began to flow at more positive potentials and became higher at the same potentials under $\mathrm{CO}_{2}$ atmosphere than those under $\mathrm{N}_{2}$ atmosphere in both solutions. When the $\mathrm{pH}$ values were adjusted to the same ones under both atmospheres, the difference between the current under $\mathrm{CO}_{2}$ atmosphere and that under $\mathrm{N}_{2}$ atmosphere corresponded to the reduction current of $\mathrm{CO}_{2}$. The $\mathrm{ZnO}$ was confirmed to have a significant catalytic activity for the electroreduction of $\mathrm{CO}_{2}$.

Figures 2, 3, 4, 5, and 6 illustrate the faradaic efficiencies, $\eta$ 's, on the sintered $\mathrm{ZnO}$ electrode for $40 \mathrm{C}$ at 298 $\mathrm{K}$ for electroreduction products in the aqueous solutions of $\mathrm{KHCO}_{3}, \mathrm{~K}_{2} \mathrm{SO}_{4}, \mathrm{KH}_{2} \mathrm{PO}_{4}, \mathrm{~K}_{2} \mathrm{HPO}_{4}$, and $\mathrm{K}_{3} \mathrm{PO}_{4}$ with respect to the electrode potential, $E$. In all the solutions, the electroreduction products were $\mathrm{CO}$ and $\mathrm{H}_{2}$ with a trace amount (less than $0.01 \%$ ) of $\mathrm{HCOO}^{-}$. No hydrocarbon and alcohol were detected. In the $\mathrm{KHCO}_{3}$ and $\mathrm{K}_{2} \mathrm{SO}_{4}$ solutions, the dependence on the electrode potential of the products on the $\mathrm{ZnO}$ electrode was almost the same as that on the zinc foil electrode; namely $\mathrm{CO}$ was the main reduction product, the efficiency maximum of which reached about $70 \%$ in the $\mathrm{KHCO}_{3}$ solution at

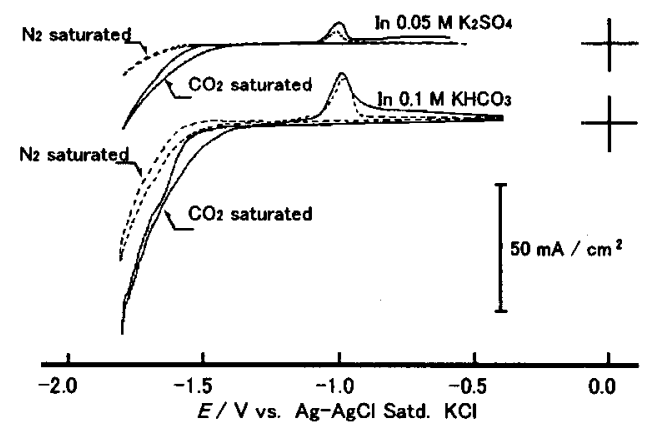

Fig. 1 Cyclic voltammograms on the $\mathrm{ZnO}$ electrode in aqueous $0.1 \mathrm{M} \mathrm{KHCO}_{3}$ and $0.05 \mathrm{M} \mathrm{K}_{2} \mathrm{SO}_{4}$ solutions under $\mathrm{N}_{2}$ (dotted line) or $\mathrm{CO}_{2}$ (solid line) atmosphere, respectively, at \pm 50 $\mathrm{mV} / \mathrm{s}$.

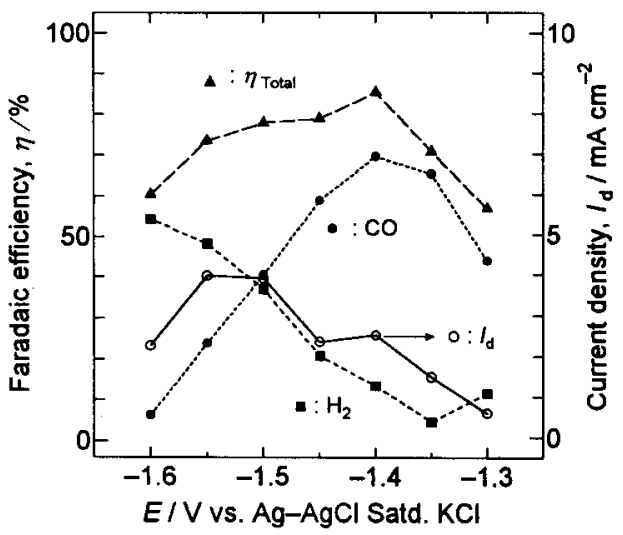

Fig. 2 Faradaic efficiency for the formation of $\mathrm{CO}$ and $\mathrm{H}_{2}$ and current density on the $\mathrm{ZnO}$ electrode in aqueous $0.1 \mathrm{M}$ $\mathrm{KHCO}_{3}$ solution as a function of the electrode potential at 298 K. (Quantity of the electricity passed: $40 \mathrm{C}$ ) around $-1.40 \mathrm{~V}$, which was $200-250 \mathrm{mV}$ nobler than that observed with $\mathrm{Zn}$ foil electrodes. ${ }^{18)}$ A considerable amount of hydrogen (5-55\%) was formed as a byproduct, the potential profile of which was opposite to that of $\mathrm{CO}$.

In the phosphate solutions, the production of $\mathrm{H}_{2}$ became predominant $(\eta>50 \%)$ at both ends of the potential region examined, i.e. $E<-1.55 \mathrm{~V}$ and $-1.35 \mathrm{~V}<E$, and the efficiency for $\mathrm{CO}_{2}$ reduction became lower than those in the $\mathrm{KHCO}_{3}$ and $\mathrm{K}_{2} \mathrm{SO}_{4}$ solutions, The $\eta$ values for $\mathrm{CO}$ formation on the $\mathrm{ZnO}$ electrode showed maxima between -1.55 and $-1.35 \mathrm{~V}$ in all the phosphate solutions and the highest value was found to be $62.5 \%$ at $-1.40 \mathrm{~V}$ in $\mathrm{K}_{2} \mathrm{HPO}_{4}$. The sums of $\eta$ were distributed between 50 and $80 \%$, and did not fulfill $100 \%$ in all the solutions examined.

\section{2 Comparison with metallic $\mathrm{Zn}$ electrode ${ }^{18)}$}

The catalytic activity of the $\mathrm{ZnO}$ electrode for $\mathrm{CO}$ formation was found to be 10 to 50 times higher than that of the $\mathrm{Zn}$ electrode, taking into account the fact that the partial current density for $\mathrm{CO}$ formation $\left(I_{\mathrm{CO}}\right)$ on the $\mathrm{ZnO}$ electrode in the $\mathrm{KH}_{2} \mathrm{PO}_{4}$ solution was 10 to 50 times greater than that on the $\mathrm{Zn}$ electrode, ${ }^{18)}$ e.g. the $I_{\mathrm{co}}$ values were 2.0 and $0.04 \mathrm{~mA} / \mathrm{cm}^{2}$ for the $\mathrm{ZnO}$ and $\mathrm{Zn}$ electrodes, respectively, at $-1.40 \mathrm{~V}$. The distributions of the

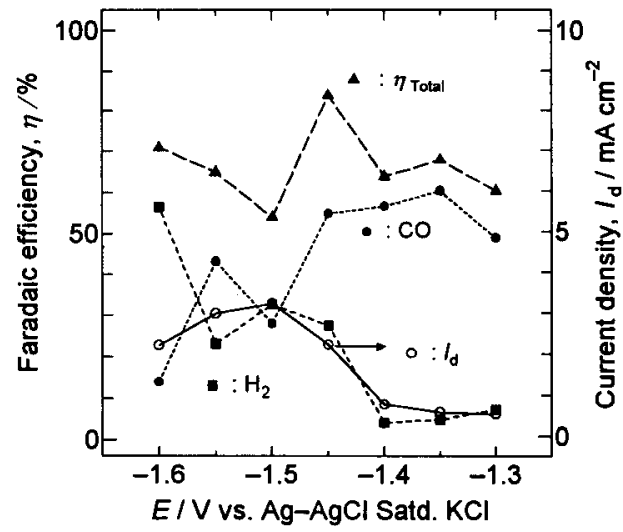

Fig. 3 Faradaic efficiency for the formation of $\mathrm{CO}$ and $\mathrm{H}_{2}$ and current density on the $\mathrm{ZnO}$ electrode in aqueous $0.05 \mathrm{M}$ $\mathrm{K}_{2} \mathrm{SO}_{4}$ solution as a function of the electrode potential at 298 K. (Quantity of the electricity passed : $40 \mathrm{C}$ )

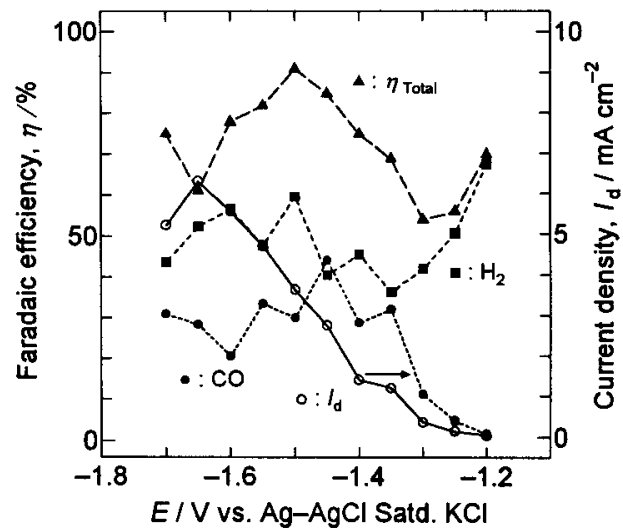

Fig. 4 Faradaic efficiency for the formation of $\mathrm{CO}$ and $\mathrm{H}_{2}$ and current density on the $\mathrm{ZnO}$ electrode in aqueous $0.1 \mathrm{M}$ $\mathrm{KH}_{2} \mathrm{PO}_{4}$ solution as a function of the electrode potential at $298 \mathrm{~K}$. (Quantity of the electricity passed : $40 \mathrm{C}$ ) 


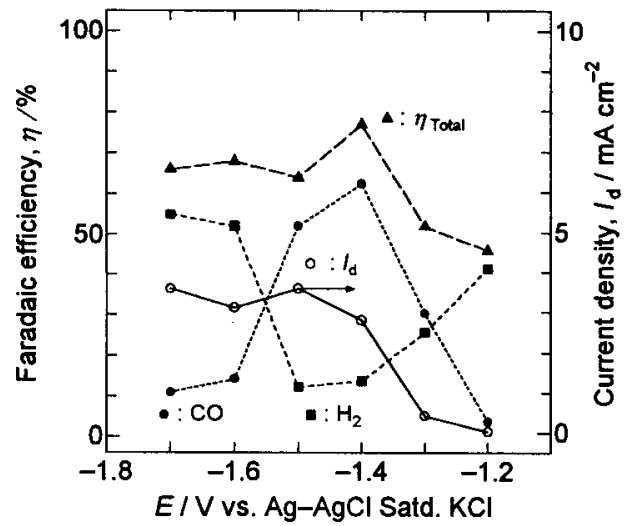

Fig. 5 Faradaic efficiency for the formation of $\mathrm{CO}$ and $\mathrm{H}_{2}$ and current density on the $\mathrm{ZnO}$ electrode in aqueous $0.05 \mathrm{M}$ $\mathrm{K}_{2} \mathrm{HPO}_{4}$ solution as a function of the electrode potential at $298 \mathrm{~K}$. (Quantity of the electricity passed : $40 \mathrm{C}$ )

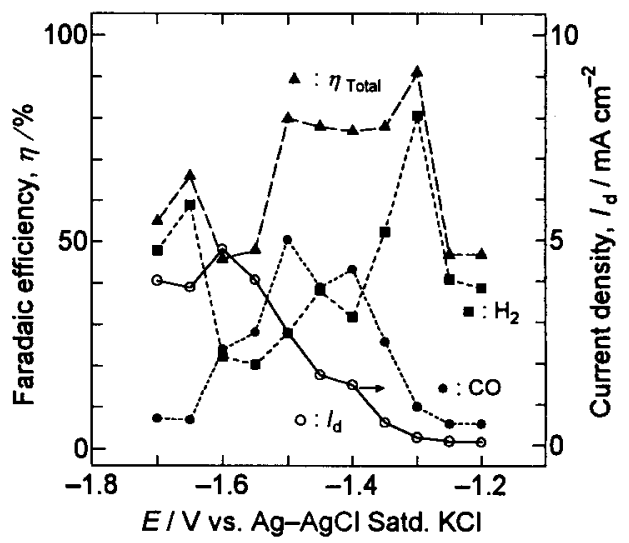

Fig. 6 Faradaic efficiency for the formation of $\mathrm{CO}$ and $\mathrm{H}_{2}$ and current density on the $\mathrm{ZnO}$ electrode in aqueous $0.1 \mathrm{M}$ $\mathrm{K}_{3} \mathrm{PO}_{4}$ solution as a function of the electrode potential at 298 K. (Quantity of the electricity passed: $40 \mathrm{C}$ )

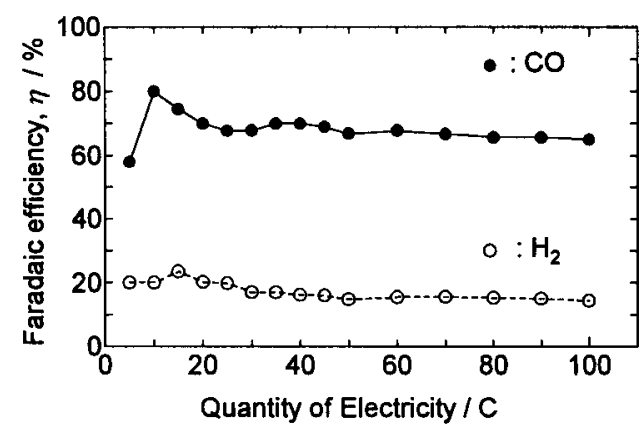

Fig. 7 Dependence of the faradaic efficiency for the formation of $\mathrm{CO}$ and $\mathrm{H}_{2}$ on the quantity of electricity passed on the $\mathrm{ZnO}$ electrode at $-1.45 \mathrm{~V}$ in $0.1 \mathrm{M} \mathrm{KHCO}_{3}$ solution at $298 \mathrm{~K}$.

reduction products in the phosphate solutions were subtly different from those obtained with the metallic $\mathrm{Zn}$ electrode, ${ }^{18)}$ where the $\eta$ value for $\mathrm{H}_{2}$ was predominant $\left(>90 \%\right.$ at $-1.4 \mathrm{~V}$ ) and the values for $\mathrm{CO}$ and $\mathrm{HCOO}^{-}$ formation were less than 30 and $10 \%$, respectively, at the maximum at $-1.8 \mathrm{~V}$ in $0.05 \mathrm{M} \mathrm{K}_{2} \mathrm{HPO}_{4}$.

\section{3 Stability of catalytic activity of $\mathrm{ZnO}$ electrode}

The dependence of the faradaic efficiencies for the reduction products of $\mathrm{CO}_{2}$ at $-1.45 \mathrm{~V}$ in the $\mathrm{KHCO}_{3}$ solu-

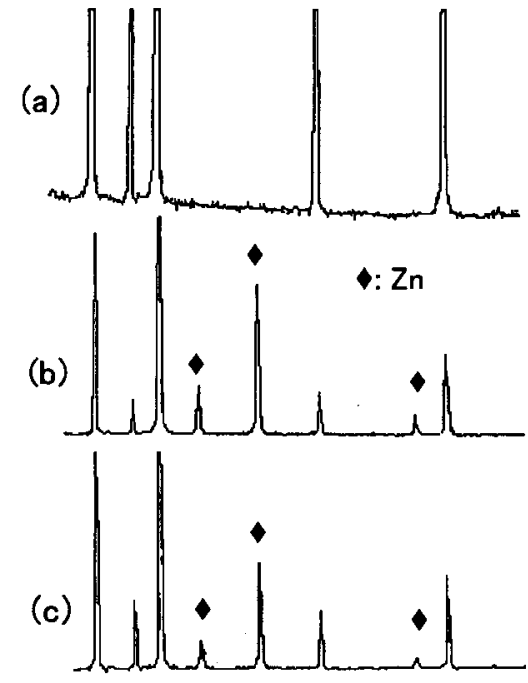

(d)

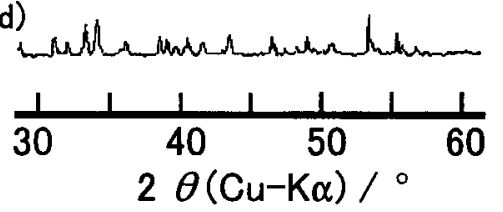

Fig. 8 XRD patterns of the $\mathrm{ZnO}$ electrode surface (a) before, (b) after electrolysis at $-1.45 \mathrm{~V}$ in $0.1 \mathrm{M} \mathrm{KHCO}_{3}$ solution, (c) surface electrolyzed at $-1.60 \mathrm{~V}$ in $0.1 \mathrm{M} \mathrm{KHCO}_{3}$ solution, and of (d) zinc formate dihydrate powder as the reference.

tion on the quantity of electricity passed was examined to confirm the stability of the electrocatalytic activity of the $\mathrm{ZnO}$ electrode, which is shown in Fig. 7. The $\eta$ Value for $\mathrm{CO}$ reached a maximum of $80 \%$ at $10 \mathrm{C}$ passed, and then decreased with increasing the quantity of electricity up to $30 \mathrm{C}$, beyond which the $\eta$ value was kept almost constant $(65 \%)$ up to $100 \mathrm{C}$. The $\eta$ value for $\mathrm{H}_{2}$ formation showed almost the same tendency as that for $\mathrm{CO}$. The $\eta$ value for $\mathrm{HCOO}^{-}$was below $0.01 \%$ up to $100 \mathrm{C}$. The time course of the current density of electroreduction of $\mathrm{CO}_{2}$ at $-1.45 \mathrm{~V}$ in the $\mathrm{KHCO}_{3}$ solution at $298 \mathrm{~K}$ increased steeply up to $30 \mathrm{~min}\left(\mathrm{ca} .7 .0 \mathrm{~mA} / \mathrm{cm}^{2}\right)$ and then gradually increased. It became approximately $9.5 \mathrm{~mA} / \mathrm{cm}^{2}$ after about $400 \mathrm{C}$ were passed for 15 hours, $i, e$. the relatively low efficiency at the initial period of the electrolysis may be due to the low current density with a low surface area of the $\mathrm{ZnO}$ electrode. As the quantity of electricity passed for the experiments were usually $40 \mathrm{C}$, the current densities presented in Figs. 2, 3, 4, 5, and 6 are mean values including the initial extremely low values.

In order to realize the deficiency from $100 \%$ in the sum of faradaic efficiencies for each product on the $\mathrm{ZnO}$ electrode, the electrode surface was investigated by XRD before and after the electrolysis for $40 \mathrm{C}$ in $0.1 \mathrm{M} \mathrm{KHCO}_{3}$. Figure 8 depicts the XRD patterns of the surfaces, with the pattern of zinc formate dihydrate powder as a reference. Apparently the peaks of $\mathrm{ZnO}$ and $\mathrm{Zn}$ were observed, while no peak related to zinc formate was found on the surface of the $\mathrm{ZnO}$ electrode after the electrolysis.

The effects of $\mathrm{Zn}$ produced on the surface of the $\mathrm{ZnO}$ electrode on electroreduction of $\mathrm{CO}_{2}$ were also examined. The changes of the rest potential of the $\mathrm{ZnO}$ electrode in 
the $\mathrm{KH}_{2} \mathrm{PO}_{4}$ solution $(40 \mathrm{ml})$ on addition of $5 \mathrm{mmol}$ of formate ions were also compared both under $\mathrm{N}_{2}$ and $\mathrm{CO}_{2}$ atmospheres to make clear the performance of the electrode. No difference in the rest potential was observed betwecn both atmospheres. However, the addition of formate ions caused a significant change of the rest potential from -0.083 to $-0.120 \mathrm{~V}$ due to the $\mathrm{pH}$ shift from 4.3 to 4.9 of the solution, which corresponded to the $-35 \mathrm{mV}$ shift of the potential.

3. 4 Dependence on $\mathrm{pH}$ and partial pressure of $\mathrm{CO}_{2}$

In order to elucidate the effect of $\mathrm{pH}$ on the electroreduction of $\mathrm{CO}_{2}$, the potentiostatic electroreduction of $\mathrm{CO}_{2}$ was carried out in phosphate buffered solutions of several $\mathrm{pH}$ values.

Figure 9 shows the relationship between the partial current density for the fomation of $\mathrm{CO}, I_{\mathrm{co}}$, and the electrode potential. It is seen that the potential-current curves are divided into three regions, i.e. the Region I ; -1.20 to $-1.35 \mathrm{~V}$, Region II ; -1.35 to $-1.55 \mathrm{~V}$, and Region III ; -1.55 to -1.70 V. In Region I, a linear relationship between the logarithm of the partial current density and the electrode potential holds at $2 \times 10^{-2}$ to $1 \times$ $10^{0} \mathrm{~mA} / \mathrm{cm}^{2}$, its Tafel slope being about $-120 \mathrm{mV} / \mathrm{dec}-$ ade at all the $\mathrm{pH}$ values. $I_{\mathrm{Co}}$ does not depend on the $\mathrm{pH}$ value in Region I. In Region II, the partial current densities in $\log$ units are dependent linearly on the potential and independent of the $\mathrm{pH}$ values with the same trend as in Region I, except that the Tafel slopes become about $-300 \mathrm{mV} /$ decade. On the other hand, the current densities depend neither on the electrode potential nor on $\mathrm{pH}$ values in RegionIII, where the diffusion limit of the $\mathrm{CO}_{2}$ might occur.

Figure 10 represents the dependence of the partial current density in the $\mathrm{KH}_{2} \mathrm{PO}_{4}$ solution for $\mathrm{CO}$ formation on the partial pressure of $\mathrm{CO}_{2} . P\left(\mathrm{CO}_{2}\right), 10$ at -1.30 and -1.40 $\mathrm{V}$, which correspond to the potentials in Regions I and II, respectively. There is a linear relationship between the

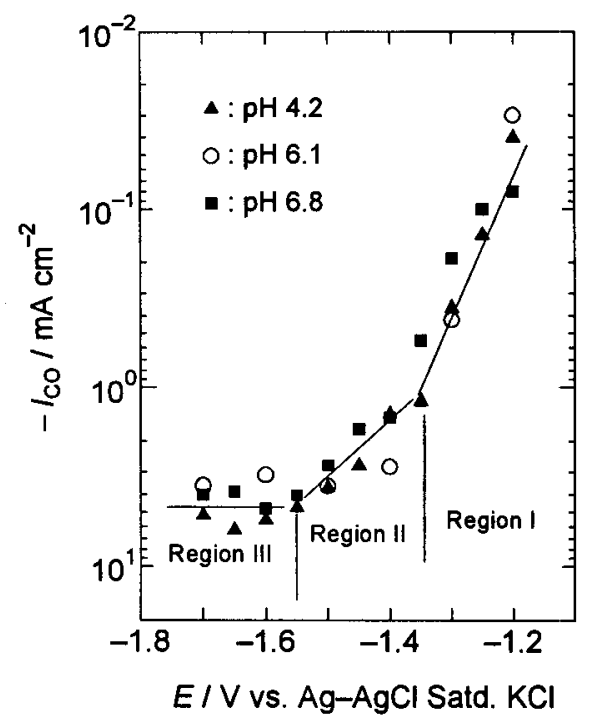

Fig. 9 Relationship between the partial current density for the formation of $\mathrm{CO}$ and the electrode potential on the $\mathrm{ZnO}$ electrode in the potassium phosphate buffer solutions with different $\mathrm{pH}$ values at $298 \mathrm{~K}$. logarithms of $I_{\mathrm{Co}}$ and $P\left(\mathrm{CO}_{2}\right)$. The slope is unity and independent of the electrode potential, $E$.

Based on the above results, the reaction order is regarded as one with respect to $\mathrm{CO}_{2}$ in Regions I and II, and $E, I_{\mathrm{co}}, m$, and $n$ values may be represented as follows. Region I :

$$
\begin{gathered}
{ }^{\mathrm{I}} E=C_{1}-(120 \pm 20) \log { }^{\mathrm{I}} I_{\mathrm{CO}} \\
{ }^{\mathrm{I}} I_{\mathrm{CO}}=C_{2}\left(P \mathrm{CO}_{2}\right)^{m} \exp (-F E / 2 R T) \\
m=\left(\partial \log { }^{\mathrm{I}} I_{\mathrm{CO}} / \partial \log P\left(\mathrm{CO}_{2}\right)\right)_{E, T}
\end{gathered}
$$

Region II :

$$
\begin{gathered}
{ }^{\mathrm{II}} \mathrm{E}=C_{3}-(300 \pm 20) \log { }^{\mathrm{I}} I_{\mathrm{CO}} \\
{ }^{\mathrm{II}} I_{\mathrm{CO}}=C_{4}\left(P\left(\mathrm{CO}_{2}\right)\right)^{n} \exp (-F E / 5 R T) \\
n=\left(\partial \log { }^{\mathrm{II}} I_{\mathrm{CO}} / \partial \log P\left(\mathrm{CO}_{2}\right)\right)_{E, T}
\end{gathered}
$$

where $C_{1}$ to $C_{4}$ denote constants, $m$ and $n$ the reaction orders of $\mathrm{CO}_{2}$ for $\mathrm{CO}$ formation, and $F, R$, and $T$ have conventional meanings.

\section{Discussion}

Carbon monoxide was selectively produced by electroreduction of $\mathrm{CO}_{2}$ on the sintered $\mathrm{ZnO}$ electrode $(\eta=$ $45-70 \%$ at a maximum) in aqueous potassium solutions, and $\mathrm{HCOO}^{-}$was hardly detected. These results differ from those in the case of $\mathrm{Zn}$ metal electrode, ${ }^{17,18)}$ where the $\mathrm{HCOO}^{-}$was produced $(\eta=5-20 \%)$ together with a large amount of $\mathrm{H}_{2}(\eta=55-95 \%)$ in the potassium phosphate solutions. In the case of the $\mathrm{ZnO}$ electrode, which was run in the $\mathrm{KH}_{2} \mathrm{PO}_{4}, \mathrm{~K}_{2} \mathrm{HPO}_{4}$, and $\mathrm{K}_{3} \mathrm{PO}_{4}$ solutions with different $\mathrm{pH}$ values each other, no significant change in the profile of the reduction products was observed, as is apparent from Figs. 4, 5, and 6. These findings indicate that the reduction current density of $\mathrm{CO}$ formation on $\mathrm{ZnO}$ should not be influenced significantly by the $\mathrm{pH}$ change.

The partial current for $\mathrm{CO}$ formation on $\mathrm{ZnO}$ was significantly larger than that on $\mathrm{Zn}{ }^{18)}$ Therefore, $\mathrm{ZnO}$ is a fairly good electrocatalyst for $\mathrm{CO}$ formation, However, the sum of the faradaic efficiencies for the reduction products, $\mathrm{CO}$ and $\mathrm{H}_{2}$, did not reach $100 \%$. The reason

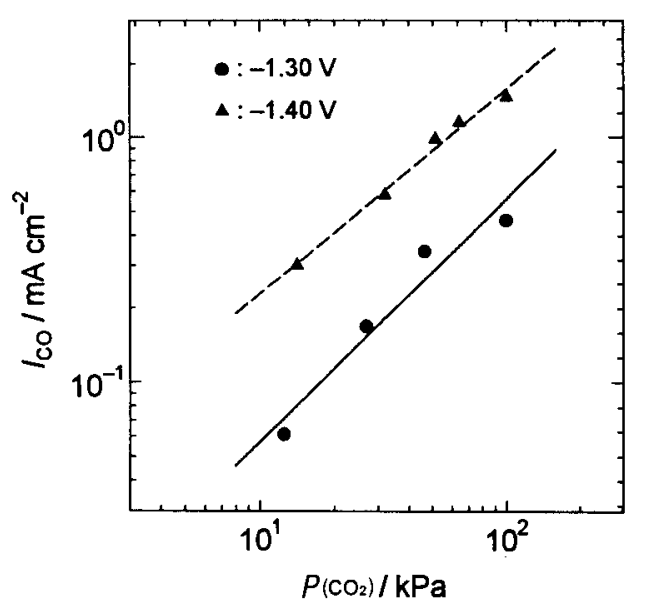

Fig. 10 Relationship between the partial current density for the formation of $\mathrm{CO}$ at $-1.30 \mathrm{~V}$ and $-1.40 \mathrm{~V}$ and the $\mathrm{CO}_{2}$ partial pressure on the $\mathrm{ZnO}$ electrode in $0.1 \mathrm{M} \mathrm{KH}_{2} \mathrm{PO}_{4}$ solution at $298 \mathrm{~K}$. 
may be ascribed to the partial reduction of $\mathrm{ZnO}$ electrode itself ${ }^{19)}$ or to the absorption of produced $\mathrm{HCOO}^{-}$ on the surface of the $\mathrm{ZnO}$ electrode. ${ }^{20)}$ The observation of the electrode surface after the electroreduction by XRD (Fig. 8) suggested the presence of $\mathrm{Zn}$ and the absence of zinc formate on the surface. Therefore, the absorption of formate ions was disproved. This was also supported by the results on the rest potential observation. Namely, the shortage of the sum of the faradaic efficiencies from $100 \%$ may be caused by the reduction of the $\mathrm{ZnO}$ electrode itself to $\mathrm{Zn}$. The amount $\mathrm{Of} \mathrm{Zn}$ produced was estimated to be about $17 \mathrm{mg}$ after $100 \mathrm{C}$ passage on the assumption of the maximum shortage value of $50 \%$. This amount corresponded to less than $2 \%$ of the initial weight of the $\mathrm{ZnO}$ electrode.

If metallic $\mathrm{Zn}$ affects the electrocatalytic activity, the production of $\mathrm{HCOO}^{-}$would become higher in the electrolysis. ${ }^{17}{ }^{18)}$ However, the dependence of the faradaic efficiencies for the reduction products $\mathrm{CO}$ and $\mathrm{H}_{2}$ on the quantity of the electricity passed was relatively constant, as is shown in Fig. 7. $\mathrm{HCOO}^{-}$was hardly observed up to $100 \mathrm{C}$ and the cathodic current was stable for more than 15 hours.

Pakhomov et al. ${ }^{13)}$ reported that the doping of $\mathrm{Zn}$ to the $\mathrm{ZnO}$ electrode did not affect the properties of the $\mathrm{ZnO}$ electrode for the electroreduction of $\mathrm{O}_{2}$ in aqueous solutions. This was also the case in the present work, where the deposited $\mathrm{Zn}$ during the electrolysis did not affect the properties of the sintered $\mathrm{ZnO}$ electrodes for the electroreduction of $\mathrm{CO}_{2}$. However, the deposited $\mathrm{Zn}$ may partially dissolve again during the electrolysis and the resulting $\mathrm{Zn}^{2+}$ ions affect the formation of $\mathrm{CO}$ from $\mathrm{CO}_{2}$ as was discussed in a previous paper. ${ }^{18)}$ Therefore, it is considered that $\mathrm{ZnO}$ maintains a high electrocatalytic activity for $\mathrm{CO}$ formation in the electroreduction of $\mathrm{CO}_{2}$ in cooperation with $\mathrm{Zn}^{2+}$ ions.

According to the kinetic analysis of the reactions for the $\mathrm{CO}$ formation, no dependence of $I_{\mathrm{CO}}$ on $\mathrm{pH}$ values was observed in potentiostatic electrolyses. Two regions having Tafel slopes of -120 and $-300 \mathrm{mV} /$ decade for the $I_{\mathrm{co}-} E$ curves were observed. The reaction order of $\mathrm{CO}_{2}$ on the $\mathrm{CO}$ formation was almost unity in both regions, Based on these results, the theoretical values of Tafel slopes, and the reaction order of $\mathrm{CO}_{2}$ derived by the Langmuir's isotherm for the adsorption, the following scheme is proposed for the mechanism of the $\mathrm{CO}$ formation. Mechanism :

or

$$
\begin{gathered}
\mathrm{CO}_{2 \text { (aa) }} \rightleftarrows \mathrm{CO}_{2 \text { (ads) }} \\
\mathrm{CO}_{2 \text { (ads) }}+\mathrm{e}^{-} \longrightarrow \mathrm{CO}_{2}{ }^{-} \text {(ads) } \\
\mathrm{CO}_{2}{ }^{-} \text {(ads) } \\
+\mathrm{H}^{+} \mathrm{B}^{-}+\mathrm{e}^{-} \longrightarrow \mathrm{CO}+\mathrm{OH}^{-}+\mathrm{B}^{-}
\end{gathered}
$$

$$
\begin{aligned}
& \mathrm{CO}_{2}{ }^{-}{ }_{(\mathrm{ads})}+\mathrm{H}^{+} \mathrm{B}^{-} \longrightarrow \mathrm{COOH}_{(\mathrm{ads})}+\mathrm{B}^{-} \\
& \mathrm{COOH}_{(\mathrm{ads})}+\mathrm{e}^{-} \longrightarrow \mathrm{CO}+\mathrm{OH}^{-}
\end{aligned}
$$

In the scheme $\mathrm{B}^{-}$denotes an appropriate counter anion of the supporting electrolyte, $\longrightarrow$ the rate determining step, and $d_{(a q)}$ and (ads) $_{\text {a }}$ The hydrated and adsorbed states, respectively.

\section{Conclusion}

Sintered $\mathrm{ZnO}$ electrodes partially covered with $\mathrm{Zn}$ formed during reduction processes were found to have a higher electrocatalytic activity for formation of $\mathrm{CO}$ from $\mathrm{CO}_{2}$ than the metallic $\mathrm{Zn}$ electrodes ${ }^{18)}$ in aqueous potassium salt solutions. The results support the observations in the electrolysis using the $\mathrm{Zn}$ electrode pretreated in $\mathrm{K}_{2} \mathrm{SO}_{4}$ solution, where $\mathrm{ZnO}$ occurred on the surface of the electrode, The similar results were obtained by addition of $\mathrm{Zn}^{2+}$ ions to a $\mathrm{KHCO}_{3}$ solution, Where the efficiency for $\mathrm{CO}$ formation reached $70 \%$ with $\mathrm{HCOO}^{-}$formation at a lower efficiency being accompanied. The further spectroscopic investigations should be required to identify intermediate species and pathways for $\mathrm{CO}$ formation on metallic and oxide electrodes.

\section{Acknowledgement}

This work was partially supported by Grant-in-Aid for Priority Area (Nos. 03203232 and 04201106) from the Ministry of Education, Science, Sports, and Culture, Japan.

\section{References}

1) Y. Hori, K. Kikuchi, and S. Suzuki, Chem. Lett., 1985, 1695.

2) H. Noda, S. Ikeda, Y. Oda, K. Imai, M. Maeda, and K. Ito, Bull. Chem. Soc. Jpn., 63, 2459 (1990).

3) S. Ikeda, T. Takagi, and K. Ito, Bull. Chem. Soc. Jpn., 60, 2517 (1987).

4) M. Azuma, K. Hashimoto, M. Hiramoto, M. Watanabe, and T. Sakata, J. Electrochem. Soc., 137, 1772 (1990).

5) K. Ito, S. Ikeda, N. Yamauchi, T. Iida, and T. Takagi, Bull. Chem. Soc. Jpn., 58, 3027 (1985).

6) H. Noda, S. Ikeda, A. Yamamoto, H. Einaga, and K. Ito, Bull. Chem. Soc. Jpn., 68, 1889 (1995).

7) K. Ogura and M. Takagi, Solar Energy, 37, 41 (1986).

8) O. De Nora, Chem. Ing. Techn. 42, 222 (1970).

9) A. T. Kuhn and C. S. Mortimer, J. Electrochem. Soc., 120, 231 (1973).

10) A. Bandi, I. Vartires, A. Mihelis, and C. Hainarosie, $J$. Electroanal. Chem., 157, 241 (1983).

11) A. Bandi, A. Mihelis, I. Vartires, E. Ciortan, and I. Rosu, J. Electrochem. Soc., 134, 1982 (1987).

12) S. Trasatti and G. Lodi, Electrodes of Conductive Metallic Oxide, (Ed. S. Trasatti), Elsevier Science Publishers, P. V., Amsterdam (1981).

13) V. P. Pakhomov, D. M. Shub, and V. I. Veselovskii, Electrokhimiya, 5, 843 (1969).

14) A. Bandi, J. Electrochem. Soc., 137, 2157 (1990).

15) K. W. Frese Jr., J. Electrochem. Soc., 138, 3338 (1991).

16) N. Fururya and E. Ono, Abstr. 57 th Annual Meeting of Electrochemical Sociely of Japan, April, Kyoto, 2C03, p. 47 (1990)

17) A. Hattori, H. Noda, S. Ikeda, M. Maeda, and K. Ito, Denki Kagaku (presently Electrochemistry), 59, 528 (1991).

18) S. Ikeda, A. Hattori, K. Ito, and H. Noda, Electrochemistry, 67, 27 (1999).

19) H. Gerischer, J. Electroanal. Chem., 82, 133 (1977).

20) V. Nato, K. Fukuda, T. Onishi, and K. Tamaru, J. Phys. Chem., 81, 808 (1977). 